\title{
Pengaruh Paclobutrazol dan Benzyl Adenin terhadap Pertumbuhan dan Multiplikasi Tunas Bawang Merah (Allium cepa L.) Varietas Bima Brebes secara In Vitro
}

\section{Effect of Paclobutrazol and Benzyl Adenine on In Vitro Growth and Shoot Multiplication of Shallot (Allium cepa L.) Varieties Bima Brebes}

\author{
Vivi Fitriani' ${ }^{1}$, Darda Efendi ${ }^{1,2^{*}}$ \\ ${ }^{1}$ Departemen Agronomi dan Horikultura, Fakultas Pertanian, Institut Pertanian Bogor \\ Jalan Meranti, Kampus IPB Darmaga, Bogor 16680, Indonesia \\ ${ }^{2}$ Pusat Kajian Hortikultura Tropika, Lembaga Penelitian dan Pengabdian pada Masyarakat Institut Pertanian Bogor, \\ Jl. Raya Pajajaran, Kampus IPB Baranangsiang, Bogor, Indonesia
}

Diterima 31 Mei 2018/Disetujui 11 Juni 2018

\begin{abstract}
In vitro techniques is another way that can provide a number of plants in a relatively quick, free of pathogens, or virus, and available without being affected by season. This research aims to study the effect of paclobutrazol and benzyl adenine on in vitro growth and shoot multiplication of shallot (Allium cepa L.) varieti Bima Brebes. The experiment was arranged in a Randomized Complete Block Design with two factor, the first factor consists of paclobutrazol of four levels (0.0 ppm, $2.5 \mathrm{ppm}, 5.0 \mathrm{ppm}$ and $7.5 \mathrm{ppm})$, and the second factor is the concentration of benzyl adenine consists of three levels (0.0 mg $L^{-1}, 0.5 \mathrm{mg} \mathrm{L}^{-1}$ and $\left.1.0 \mathrm{mg} \mathrm{L}^{-1}\right)$, in order to obtain 12 combinations of treatments and every treatments consist of 3 repetion. Results from this study indicate that the effect of paclobutrazol and benzyl adenine was no interaction in the number of shoots, leaves, roots, and lenght of root in of Bima Brebes during 10 MST. The persentage of live explants as a whole is $84.03 \%$. There is no significance effect of paclobutrazol on the number of shoots, number of leaves, number of roots, and leaf lenght shallot of explants. Treatments of benzyl adenin were only have significance effect on the number of shoots and number of leaves shallot of explants, but no significance effect on the number the variable leaf colors, number of roots, and leaf lenght shallot of explants.
\end{abstract}

Keywords: concentration, explants, multiplication, shallot, treatment

\section{ABSTRAK}

Teknik in vitro merupakan cara lain yang dapat menyediakan sejumlah bibit tanaman dalam waktu yang relatif cepat, bebas dari patogen atau virus, dan tersedia tanpa dipengaruhi musim. Penelitian ini bertujuan untuk mempelajari pengaruh paclobutrazol dan benzyl adenin terhadap pertumbuhan dan multiplikasi tunas bawang merah (Allium cepa L.) varietas Bima Brebes secara in vitro. Rancangan percobaan yang digunakan adalah Rancangan Kelompok Lengkap Teracak (RKLT) dua faktor, yaitu faktor pertama konsentrasi paclobutrazol yang terdiri atas empat taraf (0.0 ppm, 2.5 ppm, 5.0 ppm, dan 7.5 ppm), dan faktor kedua konsentrasi benzyl adenin yang terdiri atas tiga taraf $\left(0.0 \mathrm{mg} \mathrm{L}^{-1}, 0.5 \mathrm{mg} \mathrm{L} \mathrm{L}^{-1}\right.$, dan $\left.1.0 \mathrm{mg} \mathrm{L^{-1 }}\right) \mathrm{sehingga}$ terdapat 12 kombinasi perlakuan dan setiap perlakuan diulang sebanyak 3 kali. Hasil dari penelitian ini menunjukkan bahwa tidak ada interaksi yang nyata antara paclobutrazol dan benzyl adenine terhadap jumlah tunas, jumlah daun, jumlah akar,dan panjang akar bawang merah Bima Brebes selama 10 MST. Presentase eksplan yang hidup secara keseluruhan yaitu $84.03 \%$. Tidak ada interaksi yang nyata antara paclobutrazol dan benzyl adenin terhadap semua peubah yang diamati secara in vitro. Perlakuan paclobutrazol secara tunggal juga tidak berpengaruh nyata pada jumlah tunas, jumlah daun, jumlah akar, dan panjang daun eksplan bawang merah. Perlakuan benzyl adenin secara tunggal menyebabkan respon berbeda nyata pada peubah jumlah tunas dan jumlah daun eksplan bawang merah, tetapi tidak berbeda nyata pada peubah warna daun, jumlah akar, dan panjang daun.

Kata kunci: bawang merah, eksplan, konsentrasi, multiplikasi, perlakuan

\footnotetext{
* Penulis untuk korespondensi. e-mail: dardaefendi@yahoo.com
} 


\section{PENDAHULUAN}

Bawang merah (Allium cepa group agregatum atau Allium ascalonicum) merupakan tanaman semusim yang banyak dibutuhkan dalam kehidupan sehari-hari dan memiliki nilai ekonomi tinggi. Bawang merah digemari karena karakteristik rasa dan aroma yang khas serta kandungan minyak eteris alliin dari tanaman ini sehingga dikenal oleh masyarakat sebagai penyedap rasa atau bumbu masakan. Menurut Permadi dan Van der Meer (1997) setiap $100 \mathrm{~g}$ umbi lapis bawang merah yang dimakan terkandung $88 \mathrm{~g}$ air, $1.5 \mathrm{~g}$ protein, $6.3 \mathrm{~g}$ lemak, $9 \mathrm{~g}$ karbohidrat, $0.7 \mathrm{~g}$ serat, $0.6 \mathrm{~g}$ abu, $40 \mathrm{mg}$ P, $0.8 \mathrm{mg} \mathrm{Fe}, 36 \mathrm{mg} \mathrm{Ca}, 5 \mathrm{IU}$ vitamin $\mathrm{A}, 0.03 \mathrm{mg}$ vitamin $\mathrm{B} 1,2 \mathrm{mg}$ vitamin $\mathrm{C}$ dengan nilai energi $160 \mathrm{~kJ} / 100 \mathrm{~g}$.

Kebutuhan bawang merah meningkat secara fluktuatif karena hampir semua masakan membutuhkan komoditas ini. Produktivitas bawang merah mengalami penurunan dari 9.57 ton ha ${ }^{-1}$ pada tahun 2010 menjadi 9.54 ton ha $^{-1}$ pada tahun 2011 (BPS 2014). Penurunan produktivitas bawang merah salah satunya disebabkan karena penggunaan benih yang tidak berkualitas, penggunaan benih yang berasal dari pertanaman sebelumnya, akumulasi patogen pada tanaman dan tidak adanya sistem penangkaran benih yang dapat menimbulkan penyakit degeneratif yang akan mempengaruhi pertumbuhan dan produksi tanaman bawang merah di lapangan. Menurut data dari Badan Pusat Statistik (2014), bahwa produksi bawang merah di Indonesia dalam kurun waktu 2010-2014 menunjukkan angka peningkatan dari 1,048,934 ton menjadi $1,233,948$ ton atau dengan laju 22.08 persen per tahun. Peningkatan produksi tersebut disebabkan oleh peningkatan produktivitas dengan laju 0.07 persen per tahun.

Perbanyakan bawang merah secara kultur jaringan dapat dilakukan untuk pengadaan umbi bibit yang bebas patogen dan virus, sehat, cepat, serta kontinyu. Perbanyakan bawang merah dengan metode kultur jaringan yaitu dengan menggunakan eksplan bassal plate (cakram umbi lapis) yang merupakan bagian meristematik. Menurut Gunawan (1992) salah satu metode perbanyakan tanaman berkualitas tinggi adalah menggunakan teknik kultur jaringan. Faktor yang mempengaruhi laju keberhasilan kultur jaringan salah satunya adalah ukuran eksplan yang digunakan. Hal itu penting dalam upaya memproduksi tanaman bebas virus melalui kultur meristem dan menentukan laju kehidupan bahan eksplan yang dikulturkan. George dan Sherrington (1984) menyatakan bahwa semakin kecil ukuran eksplan, akan semakin kecil kemungkinan terjadinya kontaminasi, baik secara internal maupun eksternal, dan laju kehidupan pun akan rendah.

Penambahan paclobutrazol dan sitokinin (benzyl adenin) diperlukan untuk merangsang pembentukan umbi secara in vitro dan efektif menurunkan pertumbuhan vegetatif tanaman sehingga penggunaan zat tersebut dapat merangsang terjadinya pengumbian.Sejalan dengan laporan Yusnita (2004) bahwa setiap genotipe (varietas) tanaman membutuhkan komposisi media tertentu guna mendukung pertumbuhan eksplan yang optimal. Aspek penting yang harus diperhatikan pada komposisi suatu media yaitu kebutuhan terhadap zat pengatur tumbuh, khususnya kombinasi dan konsentrasi dari zat pengatur tumbuh yang digunakan (Yuliarti 2010). Berdasarkan penelitian Dinarti (2012) pemberian paclobutrazol berpengaruh nyata terhadap tinggi tanaman, jumlah daun senesen, jumlah akar, dan panjang akar. Pemberian paclobutrazol pada taraf 10 mg L ${ }^{-1}$ menghambat tinggi tanaman, jumlah daun senesen, dan panjang akar. Pemberian paclobutrazol pada kosentrasi 0.1-10 $\mathrm{mg} \mathrm{L}^{-1}$ menurunkan panjang akar. Oleh karena itu, pemberian paclobutrazol pada konsentrasi 0-7.5 $\mathrm{mg} \mathrm{L}^{-1}$ diharapkan dapat menekan pertumbuhan tunas bawang merah, menghambat tinggi tanaman, tingkat kontaminasi, dan menghasilkan bibit yang berkualitas.

Penelitian ini bertujuan untuk mempelajari pengaruh paclobutrazol dan benzyl adenin terhadap pertumbuhan dan multiplikasi tunas tanaman bawang merah (Allium cepa L.) varietas Bima Brebes secara in vitro.

\section{BAHAN DAN METODE}

Penelitian ini dilaksanakan di Laboratorium Kultur Jaringan Pusat Kajian Hortikultura Tropika (PKHT), kampus IPBBaranangsiang. Kegiatanpenelitianinidilaksanakanpada bulan Februari 2015 sampai dengan bulan September 2015. Bahan yang digunakan diantaranya bawang merah varietas Bima Brebes, agar, gula, pacloburazol, sitokinin (BA), akuades, alkohol 70\%, plastik, arang sekam, dan kompos. Alat yang digunakan adalah autuclave, oven, Laminar Air Flow Cabinet, alat-alat diseksi, bak plastik, komputer, kamera serta peralatan laboratorium pada umumnya. Percobaan terdiri dari dua faktor yang disusun dalam rancangan kelompok lengkap teracak (RKLT). Faktor pertama adalah konsentrasi paclobutrazol yang terdiri atas empat taraf yaitu 0.0 ppm, 2.5 ppm, 5.0 ppm, dan 7.5 ppm. Faktor kedua adalah konsentrasi benzyl adenin yang terdiri atas tiga taraf yaitu $0.0 \mathrm{mg} / 1,0.5 \mathrm{mg} / 1$, dan $1.0 \mathrm{mg} / 1$ sehingga terdapat 12 kombinasi perlakuan. Setiap perlakuan diulang sebanyak 3 kali sehingga terdapat 36 satuan percobaan. Setiap satuan percobaan membutuhkan 1 eksplan per botol sebagai satuan amatan. Pengolahan data dilakukan dengan menggunakan program SAS versi 9.0. Perlakuan yang berpengaruh nyata di uji lanjut menggunakan Duncan's Multiple Range Test (DMRT) pada taraf 5\%.

Penelitian ini dimulai dengan melakukan inisiasi bawang merah terlebih dahulu. Bawang merah dikupas terlebih dahulu kulitnya dengan menggunakan pisau. Kemudian dicuci menggunakan deterjen hingga bersih lalu dibilas dengan menggunakan air akuades sebanyak $2 \mathrm{x}$ bilas. Setelah itu, Agrept dan Banlate ditimbang sebanyak $2 \mathrm{~g} \mathrm{~L}^{-1}$ dan dilarutkan dalam $500 \mathrm{ml}$ air akuades. Bawang merah dan larutan tersebut dimasukkan kedalam labu takar lalu di shaker selama sehari semalam. Tahap selanjutnya dilakukan penanaman bawang merah dalam media MS0 dengan pH media 5.8 selama 1 minggu, selanjutnya melakukan subkultur terhadap media perlakuan yang akan digunakan sebagai sumber eksplan bawang merah dengan masingmasing konsentrasi yang berbeda. Media konsentrasi 
dibuat sesuai dengan komposisi media dasar MS ditambah paclobutrazol dan benzyl adenin dengan konsentrasi sesuai perlakuan. Sterilisasi media dilakukan dengan menggunakan autuclave pada suhu $121{ }^{\circ} \mathrm{C}$ dan tekanan 17.5 psi selama 20 menit sedangkan sterilisasi alat tanam dan botol kultur selama 30 menit. Penanaman dilakukan dengan menanam 1 eksplan/botol, eksplan berupa bassal plate dengan ukuran 0.5-1.0 mm. Suhu ruang inkubasi bawang merah yaitu 27 $28{ }^{\circ} \mathrm{C}$ dengan $\mathrm{RH} 50 \%$, dan lama penyinaran 16 jam/hari.

Pengamatan pada tahap in vitro meliputi persentase eksplan hidup, jumlah tunas, jumlah daun, jumlah akar, panjang daun, dan warna daun. Pengamatan pada tahap ex vitro meliputi panjang akar, tinggi tanaman, dan warna daun. Pengamatan dilakukan selama 10 MST (Minggu Setelah Tanam) sesuai dengan peubah yang diamati.

\section{HASIL DAN PEMBAHASAN}

\section{Kondisi Umum}

Secara umum kondisi in vitro planlet bawang merah adalah baik, dengan presentase rata-rata eksplan yang hidup secara keseluruhan yaitu 84.03\% (Tabel 1). Selama penelitian terjadi kematian eksplan dan kontaminasi pada media ataupun eksplan bawang merah. Kontaminasi yang banyak ditemukan dalam kultur jaringan adalah bakteri berwarna putih susu.

\section{Jumlah Tunas}

Gunawan (1992) menyatakan bahwa perbanyakan melalui multiplikasi tunas merupakan metode yang banyak digunakan dalam perbanyakan tanaman pada teknik kultur jaringan secara in vitro. Faktor terpenting dalam multiplikasi tanaman pada kultur jaringan adalah jumlah tunas karena dapat diindikasikan sebagai keberhasilan dalam multiplikasi. Berdasarkan hasil analisis data secara statistik diperoleh bahwa tidak ada interaksi yang nyata antara paclobutrazol dan benzyl adenin terhadap peubah jumlah tunas yang diamati pada tahap in vitro. Hal ini mungkin disebabkan konsentrasi yang diberikan antara paclobutrazol dan benzyl adenin belum mampu mempengaruhi keseimbangan zat pengatur tumbuh yang terdapat dalam tanaman itu sendiri.

Pemberian benzyl adenin secara tunggal menunjukkan pengaruh berbeda nyata terhadap peubah jumlah tunas dibandingkan pemberian paclobutrazol. Eksplan bawang merah yang diinisiasi pada media perbanyakan sudah melakukan multiplikasi tunas pada 2 MST. Konsentrasi benzyl adenin yang semakin tinggi pada penelitian menghasilkan jumlah tunas bawang merah yang rendah (Tabel 2). Benzyl adenin merupakan sitokinin yang banyak digunakan untuk induksi dan multiplikasi tunas adventif pada banyak tanaman (Gunawan 1987). Penambahan sitokinin (benzyl adenin) ke dalam media kultur dapat menstimulasi sintesis protein di dalam jaringan tanaman, sehingga mampu mendorong organogenesis kultur tunas in vitro (Salisbury dan Ross 1995).
Pemberian benzyl adenin pada konsentrasi $0.0 \mathrm{ppm}$ menghasilkan jumlah tunas relatif tinggi yaitu 0.81 tunas yang tidak berbeda nyata dengan benzyl adenin $0.5 \mathrm{ppm}$. Hal ini sejalan dengan penelitian Hanizah (2013) bahwa

Tabel 1. Rataan presentase eksplan hidup bawang merah secara in vitro

\begin{tabular}{cccccc}
\hline \multirow{5}{*}{ Perlakuan } & \multicolumn{5}{c}{ Persentase eksplan hidup (\%) } \\
\cline { 2 - 6 } & 2 & 4 & 6 & 8 & 10 \\
\cline { 2 - 6 } Paclobutrazol (ppm) \\
\hline 0 & 94.4 & 94.4 & 94.4 & 94.4 & 83.3 \\
2.5 & 94.4 & 94.4 & 83.3 & 77.7 & 66.6 \\
5 & 94.4 & 94.4 & 88.8 & 88.8 & 77.7 \\
7.5 & 100 & 100 & 100 & 100 & 100 \\
\hline \multicolumn{6}{c}{ Benzyl adenin (ppm) } \\
\hline 0 & 95.8 & 95.8 & 87.5 & 87.5 & 79.1 \\
0.5 & 100 & 100 & 95.8 & 95.8 & 87.5 \\
1 & 91.6 & 91.6 & 91.6 & 83.3 & 83.3 \\
\hline
\end{tabular}

Tabel 2. Rataan peubah jumlah tunas bawang merah in vitro pada perlakuan paclobutrazol dan benzyl adenin

\begin{tabular}{|c|c|c|c|c|c|}
\hline \multirow{3}{*}{ Perlakuan } & \multicolumn{5}{|c|}{ Jumlah tunas $^{+}$} \\
\hline & \multicolumn{5}{|c|}{ Umur (MST) } \\
\hline & 2 & 4 & 6 & 8 & 10 \\
\hline \multicolumn{6}{|c|}{ Paclobutrazol (ppm) } \\
\hline 0 & 0.5 & 0.6 & 0.6 & 0.6 & 0.6 \\
\hline 2.5 & 0.3 & 0.3 & 0.3 & 0.3 & 0.3 \\
\hline 5 & 0.6 & 0.6 & 0.6 & 0.6 & 0.6 \\
\hline 7.5 & 0.4 & 0.6 & 0.6 & 0.7 & 0.8 \\
\hline Uji F & tn & tn & tn & tn & tn \\
\hline \multicolumn{6}{|c|}{ Benzyl adenin (ppm) } \\
\hline 0 & $0.7 \mathrm{a}$ & $0.8 \mathrm{a}$ & $0.8 \mathrm{a}$ & $0.8 \mathrm{a}$ & $0.8 \mathrm{a}$ \\
\hline 0.5 & $0.5 \mathrm{ab}$ & $0.6 \mathrm{a}$ & $0.6 \mathrm{a}$ & $0.6 \mathrm{a}$ & $0.7 \mathrm{a}$ \\
\hline 1 & $0.1 \mathrm{~b}$ & $0.1 \mathrm{~b}$ & $0.1 \mathrm{~b}$ & $0.1 \mathrm{~b}$ & $0.1 \mathrm{~b}$ \\
\hline Uji F & $*$ & $*$ & $*$ & $*$ & $*$ \\
\hline
\end{tabular}

\begin{tabular}{cccccc} 
Paclo x BA & tn & tn & tn & tn & tn \\
\hline KK $(\%)$ & 17.4 & 18.1 & 18.1 & 18.7 & 18.6 \\
\hline
\end{tabular}

Keterangan : tn: tidak berbeda nyata, *: berbeda nyata pada taraf $5 \%, * *$ : sangat nyata pada taraf $1 \%$, : data yang diolah ditransformasikan ke $(x+1)^{1 / 2}$. Angka-angka yang diikuti huruf yang sama pada kolom yang sama tidak berbeda nyata pada uji DMRT taraf 5\%. 
pemberian zat pengatur BAP memberikan efek yang baik pada multiplikasi tunas. Eksplan bawang merah yang ditanam pada perlakuan benzyl adenin $0.5 \mathrm{ppm}$ dan 1.0 ppm menghasilkan 0.68 dan 0.12 tunas yang berbeda nyata dengan kontrol pada umur 10 MST. Pemberian benzyl adenin $0.0 \mathrm{ppm}$ dan 1.0 ppm menurunkan $85.18 \%$ jumlah tunas eksplan bawang merah pada 10 MST. Meskipun perlakuan benzyl adenin $0.0 \mathrm{ppm}$ dan $0.5 \mathrm{ppm}$ tidak berbeda nyata, namun dari segi penggunaan zat pengatur tumbuh, perlakuan benzyl adenin 0.0 ppm lebih efisien sehingga untuk multiplikasi tunas bawang merah tidak perlu penambahan benzyl adenin.

Menurut penelitian sebelumnya yang dilakukan oleh Dinarti (2012) bahwa jumlah tunas bawang merah dapat ditingkatkan dengan cara melakukan subkultur pada minggu ke 3-4 dan dilakukan pemisahan tunas pada media perbanyakan. Tunas tidak perlu dibiarkan terlalu lama sampai 6 MST karena data pada Tabel 2 menunjukkan setelah minggu keempat jumlah tunas bawang merah tidak bertambah.

\section{Jumlah Daun}

Perlakuan konsentrasi paclobutrazol secara tunggal menyebabkan respon yang tidak berbeda nyata pada peubah jumlah daun pada setiap minggunya secara in vitro (Tabel 3). Berdasarkan hasil analis data secara statistik, pemberian paclobutrazol pada minggu ke 8 sudah tidak menyebabkan penambahan jumlah daun hingga minggu ke 10. Hal ini

Tabel 3. Rataan peubah jumlah daun bawang merah in vitro pada perlakuan paclobutrazol dan benzyl adenin

\begin{tabular}{cccccc}
\hline Perlakuan & \multicolumn{5}{c}{ Umur $^{+}$(MST) } \\
\cline { 2 - 6 } & 2 & 4 & 6 & 8 & 10 \\
\hline \multicolumn{6}{c}{ Paclobutrazol (ppm) } \\
0 & 2.5 & 3.3 & 3.6 & 3.8 & 3.8 \\
2.5 & 2.6 & 3.8 & 3.8 & 3.9 & 3.9 \\
5 & 2.3 & 3.2 & 3.6 & 3.9 & 4.1 \\
7.5 & 2.5 & 3.9 & 4.3 & 4.3 & 4.3 \\
Uji F & tn & tn & tn & tn & tn \\
\hline \multicolumn{7}{c}{ Benzyl adenin $(\mathrm{ppm})$} & & \\
\hline 0 & 2.4 & 3.4 & $3.5 \mathrm{ab}$ & $3.4 \mathrm{ab}$ & $3.8 \mathrm{ab}$ \\
0.5 & 2.6 & 3.9 & $4.6 \mathrm{a}$ & $4.7 \mathrm{a}$ & $4.8 \mathrm{a}$ \\
1 & 2.4 & 3.3 & $3.4 \mathrm{~b}$ & $3.5 \mathrm{~b}$ & $3.5 \mathrm{~b}$ \\
Uji F & tn & tn & $*$ & $*$ & $*$ \\
Interaksi & tn & tn & tn & tn & tn \\
KK (\%) & 9.1 & 12.8 & 13.8 & 13.9 & 14 \\
\hline
\end{tabular}

Keterangan: tn: tidak berbeda nyata, *: berbeda nyata pada taraf $5 \%$, **: sangat nyata pada taraf $1 \%,{ }^{+}$: data yang diolah ditransformasikan ke $(x+0.5)^{1 / 2}$. Angka-angka yang diikuti huruf yang sama pada kolom yang sama tidak berbeda nyata pada uji DMRT taraf 5\%. sejalan dengan penelitian Syahid (2007), bahwa jumlah daun yang dihasilkan tidak berbeda nyata pada berbagai konsentrasi paclobutrazol(0.0-5.0 ppm) karena paclobutrzol tidak mempengaruhi pembentukan daun.

Perlakuan konsentrasi benzyl adenin secara tunggal menyebabkan respon berbeda nyata pada peubah jumlah daun pada 6 - 10 MST tetapi tidak berpengaruh nyata pada 2 - 4 MST yang diamati pada tahap in vitro. Jumlah daun terbanyak diperoleh pada perlakuan benzyl adenin $0.5 \mathrm{ppm}$ yaitu 4.75 pada $10 \mathrm{MST}$, yang tidak berbeda nyata dengan perlakuan benzyl adenin 0.0 ppm (kontrol). Perlakuan 1.0 ppm benzyl adenin menghasilkan jumlah daun terendah yaitu 3.50 tetapi tidak berbeda nyata dengan perlakuan kontrol. Hal ini bertolak belakang dengan penelitian Wahyanto (2005), bahwa pemberian BA mampu memperbanyak jumlah daun terbesar pada BA 6 ppm yaitu 20.55 helai.

Tunas bawang merah dalam kondisi yang baik ditunjukkan dengan daun yang berwarna hijau sehingga akan mendukung pembentukan umbi lapis bawang merah. Daun akan mengalami perubahan warna dari hijau menjadi kecoklatan karena kehilangan klorofil (senesen). Jumlah daun yang berwarna hijau mengalami penurunan mulai 4 MST pada seluruh media perlakuan (Tabel 4). Berdasarkan hasil analisis data secara statistik, bahwa tidak ada interaksi yang nyata antara paclobutrazol dan benzyl adenin terhadap peubah warna daun yang diamati pada tahap in vitro.

Secara tunggal perlakuan paclobutrazol dan benzyl adenin tidak berpengaruh nyata terhadap peubah warna daun. Menurut Wang et al. (1986) bahwa pemberian

Tabel 4. Rataan peubah warna daun bawang merah in vitro pada perlakuan paclobutrazol dan benzyl adenin

\begin{tabular}{cccccc}
\hline \multirow{6}{*}{ Perlakuan } & \multicolumn{6}{c}{ Minggu setelah tanam (MST) } \\
\cline { 2 - 6 } & 2 & 4 & 6 & 8 & 10 \\
\hline \multicolumn{5}{c}{ warna daun } \\
\hline 0 & 2.5 & 1.5 & 0.8 & 0.7 & 0.7 \\
2.5 & 2.6 & 1.8 & 1.2 & 1.1 & 0.9 \\
5 & 2.9 & 2.3 & 1.4 & 1.2 & 1 \\
7.5 & 3.1 & 1.9 & 1 & 0.7 & 0.6 \\
Uji F & tn & tn & tn & tn & tn \\
\hline \multicolumn{6}{c}{ Benzyl adenin $(\mathrm{ppm})$} \\
\hline 0 & 3.1 & 2 & 1.1 & 1 & 0.9 \\
0.5 & 2.7 & 1.7 & 0.8 & 0.7 & 0.5 \\
1 & 2.6 & 1.9 & 1.3 & 1.1 & 1 \\
Uji F & tn & tn & tn & tn & tn \\
\hline
\end{tabular}

Keterangan : tn: tidak berbeda nyata. Nilai yang diikuti oleh huruf yang sama pada kolom yang sama tidak berbeda nyata pada uji DMRT taraf 5\%. skor $0.0-1.0$ : kuning; 1.1 - 2.0 : kuning hijau; 2.1 - 3.0 : hijau muda; 3.1 - 4.0 : hijau tua 
paclobutrazol menghasilkan daun lebih hijau karena zat penghambat tersebut dapat meningkatkan kandungan klorofil pada daun. Hasil penelitian ini bertolak belakang dengan penelitian Dinarti (2012) bahwa pemberian paclobutrazol pada konsentrasi tinggi mempertahankan warna hijau pada daun in vitro. Hal ini disebabkan sel-sel daun mengecil, terakumulasi dan padat sehingga warna hijau lebih bertahan lama.

\section{Panjang Daun}

Perlakuan konsentrasi paclobutrazol dan benzyl adenin secara tunggal menyebabkan respon yang tidak berbeda nyata pada peubah panjang daun, serta tidak ada interaksi yang nyata antara paclobutrazol dan benzyl adenin terhadap peubah panjang daun yang diamati secara in vitro. Pertumbuhan bawang merah yang baik ditandai dengan meningkatnya panjang daun pada setiap minggunya. Hal ini dapat dilihat pada Tabel 6, bahwa pemberian berbagai konsentrasi paclobutrazol dan benzyl adenin belum dapat menghambat panjang daun eksplan bawang merah hingga 10 MST.

\section{Jumlah Akar}

Kemampuan bagian tanaman untuk berakar memang sangat beragam, tergantung pada jenis tanaman, umur, lingkungan, dan perlakuan-perlakuan yang diberikan. Akar

Tabel 5. Rataan peubah panjang daun bawang merah in vitro pada perlakuan paclobutrazol dan benzyl adenin

\begin{tabular}{|c|c|c|c|c|c|}
\hline \multirow{3}{*}{ Perlakuan } & \multicolumn{5}{|c|}{ Panjang daun ${ }^{+}(\mathrm{cm})$} \\
\hline & \multicolumn{5}{|c|}{ Umur (MST) } \\
\hline & 2 & 4 & 6 & 8 & 10 \\
\hline \multicolumn{6}{|c|}{ Paclobutrazol (ppm) } \\
\hline 0 & 3 & 5 & 5.9 & 6.6 & 6.6 \\
\hline 2.5 & 2.8 & 4.2 & 5.3 & 5.8 & 5.2 \\
\hline 5 & 3.1 & 4.9 & 5.2 & 6.3 & 6.5 \\
\hline 7.5 & 2.2 & 3.1 & 3.6 & 3.9 & 4 \\
\hline Uji F & tn & tn & tn & tn & tn \\
\hline \multicolumn{6}{|c|}{ Benzyl adenin (ppm) } \\
\hline 0 & 2.5 & 4.1 & 5 & 5.4 & 5.5 \\
\hline 0.5 & 3.1 & 4.9 & 5.9 & 6.5 & 6.5 \\
\hline 1 & 2.7 & 3.9 & 4.5 & 5.1 & 5.1 \\
\hline Uji F & tn & tn & tn & tn & tn \\
\hline Interaksi & & & & & \\
\hline Paclo x BA & tn & tn & tn & tn & tn \\
\hline KK $(\%)$ & 14.4 & 17.3 & 17.8 & 18.8 & 19.4 \\
\hline
\end{tabular}

Keterangan: tn: tidak berbeda nyata, *: berbeda nyata pada taraf $5 \%, * *$ : sangat nyata pada taraf $1 \%$, ${ }^{+}$: data yang diolah ditransformasikan ke $(\mathrm{x}+1.5)^{1 / 2}$. mulai terbentuk di bagian pangkal tunas pada perlakuan media paclobutrazol dan benzyl adenin. Berdasarkan data pada Tabel 5, bahwa tidak ada interaksi yang nyata antara paclobutrazol dan benzyl adenin terhadap peubah jumlah akar yang diamati pada tahap in vitro, dan secara tunggal perlakuan paclobutrazol dan benzyl adenine tidak berpengaruh nyata. Havranek dalam Novak et al. (1986) menyatakan bahwa pada tanaman bawang putih (A. Sativum) akar lebih baik tumbuh pada media tanpa ZPT. Sitokinin yang terlalu tinggi dapat menyebabkan pembentukan akar terhambat. Penelitian ini bertolak belakang dengan penelitian Dinarti (2012), bahwa pemberian paclobutrazol berpengaruh nyata terhadap jumlah akar. Hal ini diduga karena perbedaan genetik varietas yang digunakan, suhu ruang, dan intensitas cahaya ruang kultur.

Pemberian paclobutrazol secara tunggal menyebabkan respon yang tidak berbeda nyata pada peubah panjang akar dan tinggi tanaman. Tidak adanya perbedaan yang nyata pada panjang akar eksplan bawang merah menunjukkan tidak terjadi pengaruh paclobutrazol terhadap akar.Hal ini diduga paclobutrazol tidak memberikan penghambatan terhadap biosintesis auksin yang berfungsi menstimulasi pembentukan akar tetapi bekerja menghambat biosintesis giberelin.

Tinggi tanaman merupakan hasil dari pembelahan dan pemanjangan sel-sel meristem akar apikal yang distimulasi oleh zat pengatur tumbuh giberelin, sehingga kekurangan giberelin akan mengakibatkan pertumbuhan yang kerdil

Tabel 6. Rataan peubah jumlah akar bawang merah in vitro pada perlakuan paclobutrazol dan benzyl adenin

\begin{tabular}{cccccc}
\hline \multirow{2}{*}{ Perlakuan } & \multicolumn{5}{c}{ Jumlah akar $^{+}$} \\
\cline { 2 - 6 } Umur (MST) \\
\hline \multicolumn{5}{c}{ Paclobutrazol (ppm) } \\
\hline $0^{+}$ & 2.4 & 3.4 & 4.4 & 4.6 & 5 \\
$2.5^{+}$ & 2.4 & 3.1 & 3.5 & 3.8 & 4 \\
$5^{+}$ & 1.9 & 2.9 & 3.7 & 4.4 & 4.8 \\
$7.5^{+}$ & 2.8 & 4 & 4.5 & 5.3 & 5.9 \\
Uji F & tn & tn & tn & tn & tn \\
\hline \multicolumn{5}{c}{ Benzyl adenin (ppm) } \\
\hline 0 & 3.1 & 4.4 & 5.1 & 5.7 & 6.3 \\
0.5 & 1.9 & 2.6 & 3.4 & 4.2 & 4.8 \\
1 & 2.1 & 3.1 & 3.6 & 3.6 & 3.8 \\
Uji F & tn & tn & tn & tn & tn \\
Interaksi & & & & & tn \\
Paclo x BA & tn & tn & tn & tn \\
\hline KK (\%) & 18.7 & 24.3 & 25.4 & 24.3 & 24.3 \\
\hline
\end{tabular}

Keterangan : tn: tidak berbeda nyata, *: berbeda nyata pada taraf $5 \%$, **: sangat nyata pada taraf $1 \%$, ${ }^{+}$: data yang diolah ditransformasikan ke $(\mathrm{x}+2)^{1 / 2}$. 
pada tanaman. Sejalan dengan penelitian Dinarti (2012), bahwa pemberian paclobutrazol pada taraf 0.1-10 ppm menurunkan panjang akar bawang merah. Berdasarkan hasil analisis data statistik yang diperoleh bahwa perlakuan benzyl adenine berpengaruh sangat nyata terhadap peubah panjang akar, sehingga untuk menekan pertumbuhan panjang akar dan tinggi tanaman sebaiknya tidak perlu menggunakan perlakuan benzyl adenine karena pada taraf $0.0 \mathrm{ppm}$ panjang akar dan tinggi tanaman eksplan bawang merah sudah cukup baik (Tabel 7).

Tabel 7. Pengaruh perlakuan paclobutrazol dan benzyl adenine terhadap panjang akar dan tinggi tanaman pada $10 \mathrm{MST}$

\begin{tabular}{ccc}
\hline Perlakuan & $\begin{array}{c}\text { Panjang akar } \\
(\mathrm{cm})\end{array}$ & $\begin{array}{c}\text { Tinggi tanaman } \\
(\mathrm{cm})\end{array}$ \\
\hline \multicolumn{3}{c}{ Paclobutrazol $(\mathrm{ppm})$} \\
2.5 & 2.5 & 6.8 \\
5 & 2.1 & 6.1 \\
7.5 & 2.7 & 9.6 \\
Uji F & 1.1 & 3.8 \\
& tn & tn \\
\hline 0 & Benzyl adenin $(\mathrm{ppm})$ & 9.3 \\
0.5 & $4.3 \mathrm{a}$ & 5.9 \\
1 & $1.2 \mathrm{~b}$ & 4.5 \\
Uji F & $0.8 \mathrm{~b}$ & tn \\
\hline
\end{tabular}

Keterangan : Angka-angka pada kolom yang sama yang diikuti oleh huruf yang sama menunjukkan hasil tidak berbeda nyata berdasarkan uji DMRT pada taraf $5 \%$. tn: tidak berbeda nyata, $* *$ : sangat nyata pada taraf $1 \%$

\section{KESIMPULAN}

Tidak ada interaksi yang nyata antara paclobutrazol dan benzyl adenin terhadap semua peubah yang diamati secara in vitro. Perlakuan paclobutrazol secara tunggal tidak berpengaruh nyata pada jumlah tunas, jumlah daun, jumlah akar, dan panjang daun eksplan bawang merah. Perlakuan benzyl adenin secara tunggal menyebabkan respon berbeda nyata pada peubah jumlah tunas dan jumlah daun eksplan bawang merah, tetapi tidak berbeda nyata pada peubah warna daun, jumlah akar, dan panjang daun. Pemberian benzyl adenin 1.0 ppm nyata menurunkan jumlah tunas dibandingkan dengan kontrol. Pemberian benzyl adenin 0.5 ppm tidak berbeda pengaruhnya dengan perlakuan kontrol.

\section{DAFTAR PUSTAKA}

[BPS] Badan Pusat Statistik. 2014. Tabel produksi hortikultura/luas panen, produksi dan produktivitas bawang merah 2010-2014. http://www.bps.go.id [7 Januari 2016].

Dinarti, 2012. Perbanyakan dan induksi umbi lapis mikro bawang merah secara in vitro. Disertasi. Institut Pertanian Bogor. Bogor.

Gunawan, L.W. 1992. Teknik Kultur Jaringan Tumbuhan. Pusat antar Universitas. Bioteknologi. Institut Pertanian Bogor. Bogor. 304hal.

George, EF., P.D. Sherrington. 1984. Plant Propagation by Tissue Culture. England: Exegetics Limited.

Hanizah, R. 2013. Pengaruh 2.4D dan BAP terhadap multiplikasi tunas eksplan buah naga (Hylocereus costaricensis) melalui teknik kultur jaringan secara in vitro. Skripsi. Universitas Riau-Pekanbaru. Riau.

Permadi, A.H., Q.P. Van der Meer. 1997. Allium cepa L. cv. Group aggregatum. P.64-68. In. Siemonsma SS, Piluek J (Eds). Prosea. Plant Resources of South-East Asia 8. Vegetables. Prosea. Bogor Indonesia.

Rubatzky, V.E., M. Yamaguchi. 1999. World Vegetables: Principles, Production, and Nutritive Values. 2 ed. Aspen Publ., Inc. Maryland USA. 843p.

Wahyanto, T. 2005. Pengaruh konsentrasi IAA dan BA terhadap pertumbuhan eksplan bawang merah (Allium ascalonicum L.) secara in vitro. Skripsi. Universitas Negeri Semarang. Surakarta.

Wang, C.Y., G.L. Steffens, M. Fraust. 1986. Effect of paclobutrazol on accumulation carbohydrates in aple wood. Hort. Sci. 21(6): 1414-1421.

Yuliarti, N. 2010. Kultur jaringan Tanaman Skala Rumah Tangga. Lily Publisher. Yogyakarta.

Yusnita. 2004. Kultur Jaringan: Cara Memperbanyak Tanaman Secara Efisien. Agromedia Pustaka. Jakarta. 